\title{
シングルディスクハプロスコープを用いた 不同視における不等像の検討
}

\author{
山口恵・早津 宏夫 \\ 横山 利幸・金井 淳
}

順天堂大学眼科

\section{Aniseikonia measurement by single disk haploscope in anisometropia}

\author{
Megumi Yamaguchi, Hayatsu Hiroo \\ Toshiyuki Yokoyama, Atsushi Kanai
}

Department of Ophthalmology, Juntendo University School of Medicine

\begin{abstract}
要 約
不同視による不等像のために眼精疲労，複視，立体感の低下などの症状をきたしている症例にし ばしば出会う。反面，大きな不同視があっても快適に眼鏡を装用している小児も多い。1.75D以上 の不同視の症例を対象にシングルディスクハプロスコープを用いて不等像を測定し，両者間での不 等像の相違について検討した。自覚症状のないものの方が, 自覚症状のあるものよりも不等像が小 さいという傾向がみられた。近視の強い眼の像は小さく, 遠視の強い眼の像は大きく感しられると いう結果が得られた。眼鏡装用開始年令，眼鏡装用年数では不等像に有意差は見られなかった。一 般に装用に酎えられる不等像は $5 \% ， 1 \mathrm{D}$ 当たり約 $2 \% の$ 不等像が起こるといわれるが，実測值に は $1 \mathrm{D}$ 当たり 0 7.6\%で個人差があった。したがって不同視の眼鏡処方時には，個々の例で不等像 を測定することが望ましいと思われる。
\end{abstract}

連絡先（テ113）東京都文京区本郷 $3-1-3$

順天堂大学医学部附属順天堂医院眼科外来 山 口 恵

Tel. 03-3813-3111

Key words : anisometropia, Aniseikonia, single disk haploscope, subjective symptoms 


\section{Abstract}

Aniseikonia induced by anisometropia often causes secondary problems such as asthenopia, diplopia and poor stereo acuity among adults. However, there are many infants who can wear glasses comfortably even if they have severe Aniseikonia.

In this study, the correlation between the degree of aniseikonia and the degree of anisometropia was determined. The relationship between the degrees of aniseikonia and with/without subjective symptoms was evaluated. The subjects had anisometropia of more than 1.75 diopters.

The results showed the following:

1. The group with no subjective symptoms had less aniseikonia than the group with subjective symptoms.

2. Images in the myopic eyes were small and the images in the hyperopic eyes were large.

3. There were no marked differences in aniseikonia between the starting age and the length of time glasses were worn.

4. Some other studies have reported that a $2 \%$ aniseikonia per diopter can be seen. However, in our study aniseikonia of $0-7.6 \%$ per diopter was found. It was concluded that when glasses are prescribed for anisometropia, it is best to measure for aniseikonia each time.

\section{I．緒言}

不同視眼に完全矯正を行った際に起こる両眼 視の視感覚異常には不等像視とプリズム作用が ある。クラクラする, 歪んでみえる, 複視, 頭 痛, 眼痛などの症状で眼鏡装用に耐えられず, 眼精疲労, 立体感の低下などをきたしている症 例にしばしば出会う。反面, 大きな不同視があ っても快適に眼鏡装用している小児も多くいる。 今回我々はシングルディスクハプロスコープ （図1）を用いて不同視の不等像を測定し, 両 者間での不等像の相違について検討したので報 告する。

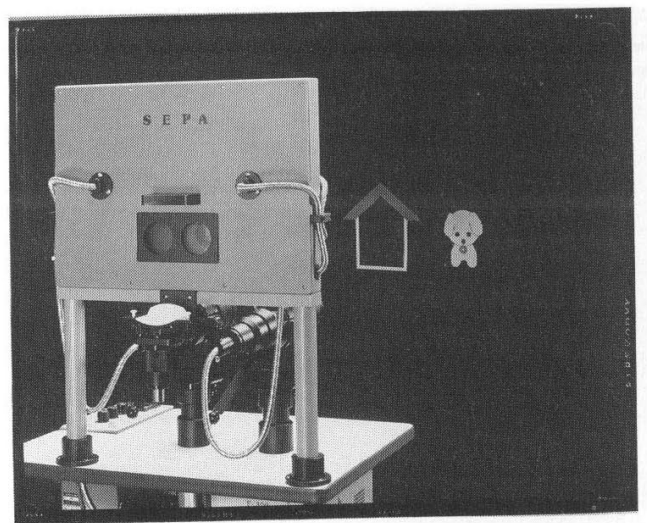

図 1. シングルディスクパプロスコープ (ビノキュラーセパ囚)

\section{II . 対象および方法}

平成 7 年 10 月から平成 8 年10月までに当院眼 科を訪れた $1.75 \mathrm{D}$ 以上の不同視のある患者 30 名 中, 左右眼で乱視の度が1.25D以上異なる者や, 軸が対称的でないものを除いた 26 名を対象とし た。乱視の度数は球面等価置換した。年齡は 5 歳から75歳 (平均 $23.5 \pm 21$ 歳), 男性10名, 女性 16名である。(強度の乱視は眼鏡レンズでの矯正 時， $1 \mathrm{D}$ につき $1.6 \%$ の不等像が生じると考えら れ ${ }^{11}$, 単眼で歪み, 違和感を起こすため除外し た。)

対象として不同視のないもの 9 例（年齢24士 4.2藏）を無作為に選択した。

不等像の測定には田川電気研究所製のシング ルディスクハプロスコープ（ビノキュラーセパ 囚）を用いて測定した。これはAulhornの位相 差ハプロスコープの原理を応用し，いくつかの 改良を加えた両眼視機能検查装置である。数個 の穴の開いた 1 枚の金属円盤が高速回転し，左 右眼が交互に刺激される。光源から出た光は光 ファイバーを通り，金属円盤により左右それぞ れの眼と時間的に同期するよう調整されてプロ ジェクターに至る。周波数は $1 \sim 120 \mathrm{~Hz}$ の間で 連続可変である。今回は全例 $50 \mathrm{~Hz}$ 以上で測定し た。プロジェクターの対物レンズはズームが可 変で, 視標の大きさが変えられる。検査距離 1 
$\mathrm{m}$, 無背景で, 不等像視用スライドを用いて測 定した。被検者にプロジェクター下部のハンド ルを持たせ，中心を合致させ，まず安静眼位を 求める。片眼に抑制がかかり，中心が合わせら れない時には優位眼の輝度を下げたり，視標を ズームレンズで拡大し，同時視が得やすくなる ようにした。プロジェクターの位置を固定し， 左右の四角の大きさに差があれば，小さいほう の像をズームレンズで拡大し，像の大きさを同 じと感じた時の四角の大きさをスクリーン上で 実測した。垂直と水平それぞれ 3 回ずつ測定し 平均した。

不等像量は（屈折異常の弱い眼の四角形の長 さ一屈折以上の強い眼の四角形の長さ） $\div$ 屈折 異常の弱い眼の四角形の長さ $\times 100(\%)$ で計算 した。

自覚症状の有無, 眼鏡装用開始年齢, 眼鏡装 用年数, 遠視性不同視と近視性不同視について 統計学的検討を行った。

\section{III. 結 果}

対照群（n=9）の不等像は垂直0.8\% $1.07 \%$, 水平 $0.78 \% \pm 1.12 \%$, 不同視群 $(\mathrm{n}=26)$ は垂直 $3.92 \% \pm 4.45 \%$ ，水平 $5.38 \% \pm 4.90 \%$ で, 有意に不同視群で不等像が大きい結果であった （ $\mathrm{P}>0.01 ）($ 図 2 )。

自覚症状の有無についての比較では, 自覚症 状のない群 $(n=20$, 不同視差平均 $3.38 \mathrm{D} \pm 1.54)$ の不等像は垂直 $2.80 \pm 3.15 \%$, 水平 $4.77 \pm 4.48 \%$, 自覚症状のある群 $(\mathrm{n}=6$, 不同視差平均 $2.65 \pm 0.85 \mathrm{D} ）$ は垂直7.94 $\pm 5.84 \%$, 水平7.96 \pm $6.15 \%$ で, 自覚症状のない群の方が不等像が小 さいという傾向があった（図 3 ）。1 D当たり の不等像を比較すると, 自覚症状のない群は垂 直 $0.87 \pm 0.77 \%$, 水平 $1.60 \pm 1.45 \%$, 自覚症状の ある群は垂直 $3.24 \pm 2.52 \%$, 水平 $2.84 \pm 2.23 \%$ で, 統計学的に有意差は認められないが自覚症状の ない群のほうが不等像が小さい傾向があった (図 4 )。眼鏡装用開始年齢は, 自覚症状のない 群は平均 $14.2 \pm 17.3$ 歳, 自覚症状のある群で $13.4 \pm 7.76$ 歳で統計学的有意差は認められなかっ た。眼鏡装用年数は自覚症状のない群は平均 $11.9 \pm 19.8$ 年, 自覚症状のある群は3.55 \pm 3.96 年
で統計学的有意差は認められなかった（図 5 )。 全体の眼鏡装用開始年齢で比較すると，12歳 未満（ $\mathrm{n}=16 ）$ は垂直 $2.84 \pm 3.96 \%$, 水平 $4.46 \pm$ $4.45 \%, 12$ 歳以降（ $\mathrm{n}=10 ）$ では垂直 $5.86 \pm$ $4.84 \%$, 水平7.68 $55.66 \%$, 12 藏以降にやや不 等像の大きい傾向が見られるものの, 有意差は なかった（図 6 )。

眼鏡装用年数の比較では, 装用開始後 5 年未 満 $(n=17)$ の不等像は垂直 $4.10 \pm 4.48 \%$, 水平 $5.40 \pm 4.65 \%, 5$ 年以上 $(n=9)$ は垂直 $3.48 \pm$ $4.68 \%$ ，水平 $5.32 \pm 6.00 \%$ で，有意差はなかった (図 7 )。

近視性不同視と遠視性不同視とでの比較では, 近視性不同視（n=12）の不等像は垂直 $4.87 \pm$ $5.53 \%$, 水平 $5.78 \pm 5.47 \%$, 遠視性不同視 $(\mathrm{n}=$ 14）は垂直 $2.71 \pm 2.19 \%$, 水平 $4.93 \pm 4.46 \%$ で, 不等像に有意差はなかった（図 8 )。不同視差 と不等像量は図 9 に示す。

\section{IV. 考按}

軸性不同視では眼鏡矯正する場合, 矯正レン ズの第 2 主点がその眼の前焦点と一致するよう に装用すれば網膜像の大きさは正常眼のそれに 等しいというKnappの法則2）3）4がある（図 10)。人間の眼の前焦点は角膜前面より約 $15.7 \mathrm{~mm}$ の点にあるとされている5 ${ }^{5}$ が, 矯正レン ズをこの点より前後にずれて装用すると網膜像 の大きさに変化を生じる。凹レンズ矯正の場合 は頂間距離が前焦点より小さければ網膜像は前 焦点の位置で矯正された像より拡大される。凸 レンズの場合は, 逆に縮小されるはずである。 今回, 頂間距離はほほ $12 \mathrm{~mm}$ 前後で測定した。 Knappの法則の前提である前焦点の位置よりも 小さい頂間距離のもとで, 即ち近視ならば網膜 像は拡大される条件で測定されているにもかか わらず，より近視性の眼の網膜像は小さく, よ り遠視性の眼の網膜像は大きいという傾向の結 果であった。これは粟屋 ${ }^{6)}$ の報告と一致する。

不同視は主として眼軸長の左右差によって成 り立っている7といわれるが, 実際の症例では 軸性因子と屈折性因子が混在するうえ, 光学的 に網膜に結像される像と, 視中枢で認識される 像には相違があるようである。 


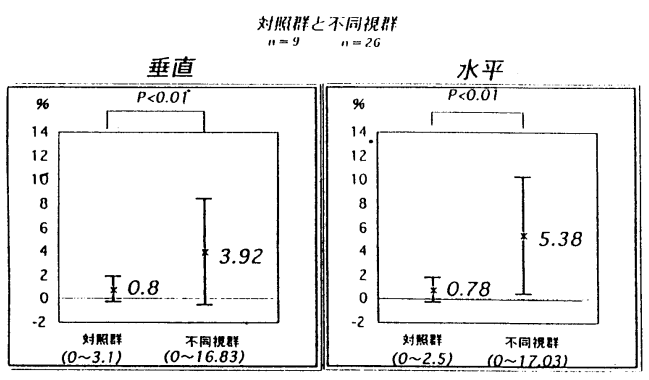

図 2. 対照群と不同視群の不等像

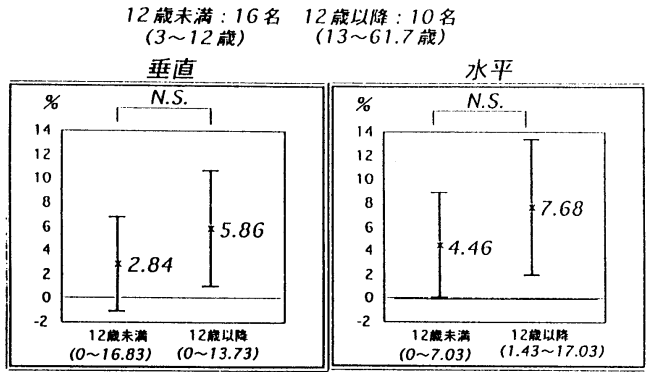

図 6 . 眼鏡装用年齢による比較

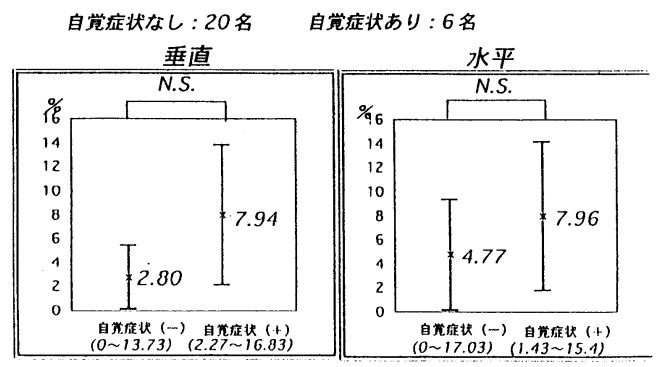

図 3．自覚症状の有無による比較（1）

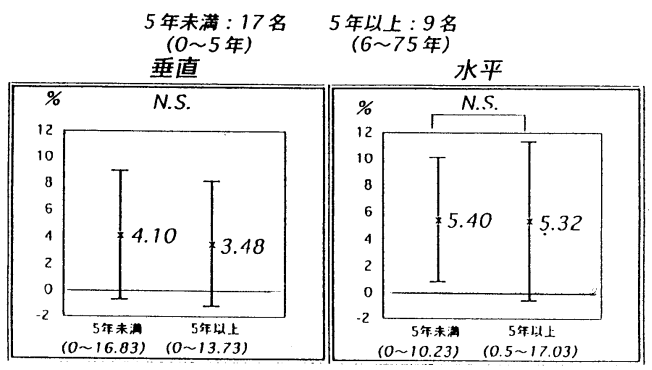

図 7. 眼鏡装用年数による比較

\section{Dあたりの不等像}

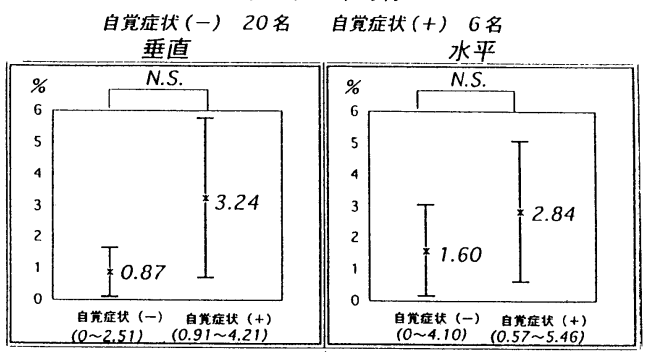

図 4. 自覚症状の有無による比較（2）

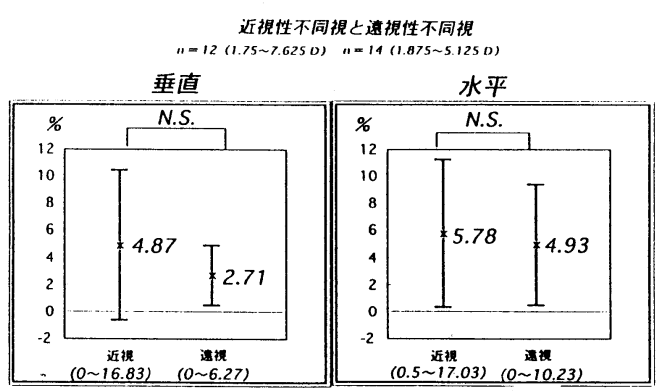

図 8. 近視性不同視と遠視性不同視
自觉症状 (一):20名 自覚症状 (十)：6名 眼鏡装用開始年撂

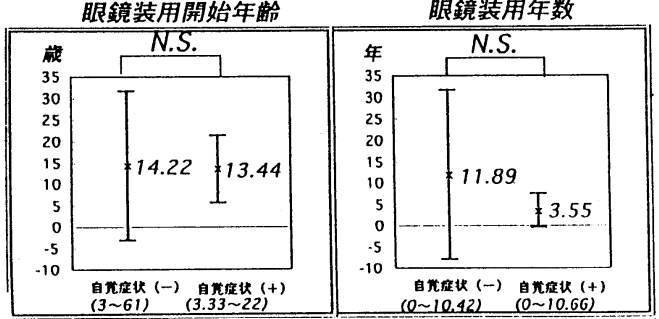

図 5.自覚症状の有無による比較（3）

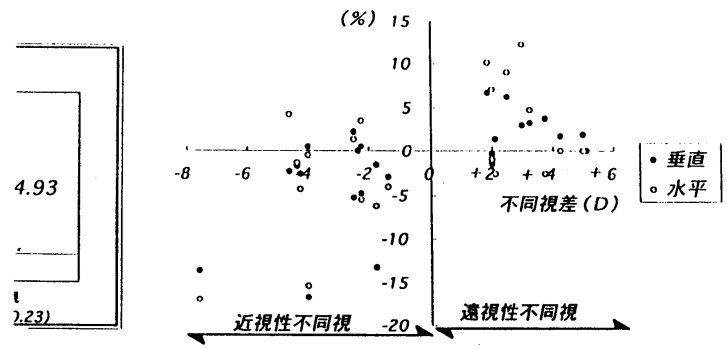

図 9. 不同視差と不等像量 


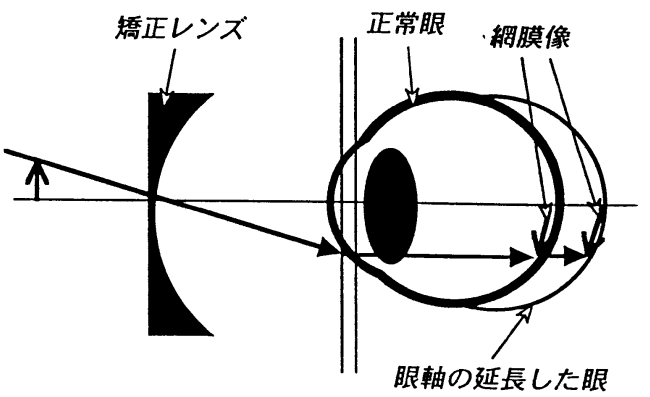

図10.Knappの法則

小児の迋視性の不同視で，アトロピン調節麻 瘏下で測定した屈折值をもとに眼鏡を装用させ ても殆どの症例で不快な自覚症状を訴えない。 遠視性不同視では軸性不同視が多く，不等像が 少ないのではないかと予想したが，今回遠視性 不同視と近視性不同視間では有意差は見られな かった。(小児では正確に眼軸長を測定するた めの協力が得られず，実際に軸性の不同視であ るのか否か検討することはできなかった。）

眼鏡装用を開始する時期について，若年者ほ ど感覚適応が起こりやすい為に不等像が小さく なるのではないかと考えたが，有意差は出なか った。今回症例数が少ないために有意差が出な かったという可能性もある。今後症例を増やし たうえで，更なる検討を加えたい。

現在市販されている不等像検査機器はPolatest やNew aniseikonia test表が代表的であるが，斜 視があると左右の像がずれ, 大きさが比較しに くいという久点がある。ハプロスコープは日常 視に近い状態での両眼視機能検査器械であり, 視方向に合わせて指標を投影できるため斜視や 斜位があっても比較的検查が容易である。また 不等像の測定と同時にレンズのプリズム効果に よるズレの定量が可能である。壁面に投影され た像を患者に見せ説明を行うとなぜ複視や眼精 疲労が起こるのか, 患者の理解が得られやすい という利点がある。

ビノキュラーセバ $囚 は$ 位相差ハプロスコープ （P D H）に比べ, 両眼の分離が完全である, 比較的狭いスペースで検查可能である, 視標の 輝度が明るく見易い（ 0 20cd/ $/ \mathrm{m}^{2}$ まで無段階 で調節できる。 P D H $\left.2.5 \mathrm{~cd} / \mathrm{m}^{2}\right)$ 等の利点が
ある。

両眼視機能検査装置としては，0 度の基準設 定がない, 平面に投影すると中心から離れるほ ど像が歪む, 目盛りがないので定量はスクリー ン上で実測しなければならない, 眼位の観察が 困難である等の欠点があり，改良の余地が残さ れている。

一般に装用に耐えられる不等像は約 $5 \%$ で 1 Dあたり約 $2 \%$ の不等像が起こるといわれる 8) が, 実測值には個人差があった。不同視の眼 鏡処方時には，個々の例で不等像を測定し，両 眼視を検查しつつ，少しでも良い立体視が得ら れる範囲で各眼の完全矯正に近付けることが望 ましいと思われる。

\section{V. 結 論}

$1.75 \mathrm{D}$ 以上の不同視の症例の不等像をシング ルディスクハプロスコープ（ビノキュラーセパ 囚）を用いて測定した。

眼鏡装用時の自覚症状の有無で比較すると自 覚症状のないもののほうが不等像が小さいとい う傾向が見られた。

眼鏡装用開始年令, 眼鏡装用年数では不等像 に有意差は見られなかった。

近視性不同視と遠視性不同視とで不等像に有 意差は見られなかった。眼鏡装用時, より近視 の強いほうの眼の像は小さく, 遠視の強いほう の像は大きく感じられるという結果が得られた。

不同視 $1 \mathrm{D}$ 当たりの不等像は $0 \sim 7.6 \%$ (平均 1.65\%）で個人差が大きい。不同視の眼鏡処方 の際には個々の症例で不等像の測定をするのが 望ましいと思われる。

シングルディスクハプロスコープは不同視の 不等像の検査に有用であった。

\section{文献}

1）保坂明郎：乱視, 市川宏他編 149-150, 新臨床 眼科全書 $3 \mathrm{~A}$, 眼光学 1 , 金原出版, 東京都, 1989.

2 ) 粟屋忍: 不等像視, 74-77, 丸尾敏夫編, 眼科 プラクティス 9 , 屈折異常の診療, 光文堂, 東京都, 1994. 
3 ）所敬：屈折異常, 172-177, 屈折異常とその短 正-改訂第二版, 金原出版, 1992.

4) 莱屋忍：不同視の稪正法 - Knappの法則, New Aniseikonia Tests, 両眼の矯正視力差, レンズのプリズム効果などよりみた検討, 眼 臨, $77: 1407-1416,1983$.

5 ）大島祐之 : 眼前 $15 \mathrm{~mm}$ に装用の眼鏡と不等像, 臨眼, $26: 1423-1427,1972$.

6）粟屋忍：Anisometoropiaにおける"Phase Difference Haploscope"によるAniseikoniaの 測定一Knappの法則及び眼鏡レンズとContact Lens矯正による倹討, 日本C.L.学会誌 $13 ： 131$ $139,1971$.

7 ）保坂明郎：不同視，161-175, 新臨床眼科全書 $3 \mathrm{~A}$, 眼光学 1 , 金原出版, 東京都, 1989 .

8 ) 保坂明郎: 不同視眼の屈折矯正と不等像視, 眼科Mook, No. 18：157-166, 1982.

質問（愛知県 眼科やがさき医院 矢ヶ㠃悌司） 1. 不等像の検查の場合, 左右眼の不等像視標を 近接させると sensory adaptationがより強く 出て検查結果にばらつきが生じますが，この 点の配慮はいかがされましたか?

\section{答弁}

1.視標は重ねあわせるのは中心だけであり, 実 際不等像を比較する辺は左右対称ではあるが 融像することはないと考える。従って日常視 時のほうがsensory adaptationは強く働いて いると思われる。SEPAの利点は「日常視 に近い条件での検査」であるので, 格別の配 虑は行わなかった。
質問 （市立札幌病院眼科 福田 雅子） 1. 迋視性不同視患者に対して不等像視を測定し た際, 弱視治療前の測定值と治療経過中視力 向上後の測定值に変化の見られた症例はみら れなかったでしょうか。

\section{答弁}

1.今回そのような症例での測定は行っていない。

質問 (名古屋市 眼科三宅病院 三宅 三平)

1. 今回の検查法のような分離視の強い方法で得 られる值は大きくなるか, 眼位が不安定にな ることなどで検査がしにくくなることがあり ます。これに対して何らかの処置をされまし たか?

\section{答弁}

1.今回は無背景で測定した結果をまとめたが, 背景があるとより sensory adaptationが強く 出て，不等像が小さくなる傾向がある。

1. 視標を近付けると片眼に抑制がかかる場合や, 眼位が不安定で中心が重ね合わせられない時 には, 少し間をあけて平行に並べるよう指導 し測定した。さらに像をズームアップすると 抑制がかかりにくくなる。 (大阪大学 不二門 尚) 1. 視標の呈示方法及び視標を四角にした理由。

\section{答弁}

1. 呈示方法は本文中に記載。視標は半円型より も中心がはっきりしているので，低年令の被 検者にも説明し易いと考える。 